\title{
Role of ciliates and other microzooplankton in the Irminger Sea (NW Atlantic Ocean)
}

\author{
David J. S. Montagnes ${ }^{1, *}$, John Allen ${ }^{2}$, Louise Brown ${ }^{2,5}$, Celia Bulit', \\ Russell Davidson ${ }^{2}$, Sophie Fielding ${ }^{2}$, Mike Heath ${ }^{4}$, N. Penny Holliday ${ }^{2}$, \\ Jens Rasmussen $^{4}$, Richard Sanders ${ }^{2}$, Joanna J. Waniek ${ }^{2,6}$, David Wilson ${ }^{1}$ \\ ${ }^{1}$ School of Biological Sciences, University of Liverpool, Biosciences Building, Crown Street, Liverpool L69 7ZB, UK \\ ${ }^{2}$ National Oceanography Centre, University of Southampton Waterfront Campus, European Way, Southampton SO14 3ZH, UK \\ ${ }^{3}$ Departamento El Hombre y su Ambiente, Universidad Autónoma Metropolitana-Xochimilco, Calzada del Hueso 1100, \\ 04960 México DF, Mexico \\ ${ }^{4}$ Marine Scotland Science, PO Box 101, 375 Victoria Road, Aberdeen AB11 9BD, UK \\ ${ }^{5}$ Present address: School of Geography and Geosciences, University of St Andrews, Irvine Building, St Andrews, \\ Fife KY16 9AL, UK \\ ${ }^{6}$ Present address: Leibniz-Institut für Ostseeforschung Warnemüde 15, 18119 Rostock, Germany
}

\begin{abstract}
This study focuses on a large region of the open ocean where we predict that microzooplankton significantly influence foodweb structure over much of the year. The Irminger Sea exhibits low primary production that is generally poor for copepod production; in such waters, ciliates and other microzooplankton are major grazers of primary production and contribute significantly to the diets of holo- and mero-mesozooplankton. Surface plankton samples were collected during an extensive survey across the basin and along one transect at several depths, over 3 seasons (winter, spring, summer), but not including the spring bloom. Microzooplankton and phytoplankton samples were fixed with Lugol's solution and microscopically enumerated for species abundance; biomass was determined from cell volumes. Basin-scale distributions of abundance, biomass, and production were examined by geostatistical and multidimensional scaling methods. Dominance of the $<10 \mu \mathrm{m}$ phytoplankton suggests that this should be a microzooplankton-dominated food web. Ciliates and heterotrophic dinoflagellates are abundant in terms of numbers and biomass; heterotrophic dinoflagellates are more abundant than ciliates, but are less dominant in terms of biomass. Using ciliates as a proxy for all microzooplankton, we suggest that there are seasonal patterns in occurrence, and there is no basin-scale patchiness related to hydrographic features. We suggest that ciliate production is sufficient to account for the removal of 15 to $30 \%$ of the $<10 \mu \mathrm{m}$ primary production. If heterotrophic dinoflagellates were included in these estimates, removal may be doubled (i.e. 30 to $60 \%$ ). We therefore contend that microzooplankton are major phytoplankton consumers in the system and should be carefully parameterised in models of this region.
\end{abstract}

KEY WORDS: Ciliates · Biomass $\cdot$ Food web $\cdot$ Nanoplankton $\cdot$ Picoplankton $\cdot$ Phytoplankton Resale or republication not permitted without written consent of the publishe

\section{INTRODUCTION}

In open-ocean systems, small phytoplankton dominate the autotrophic biomass; in these systems, microzooplankton (e.g. ciliates, heterotrophic dinoflagellates), rather than mesozooplankton, are the main grazers, structuring the system towards a microbial food web (Azam et al. 1983, Calbet 2008). This study focuses on one large region of the open ocean, the Irminger Sea (Fig. 1), where we predict that microzooplankton can significantly influence the foodweb structure, both by recycling materials within the upper 


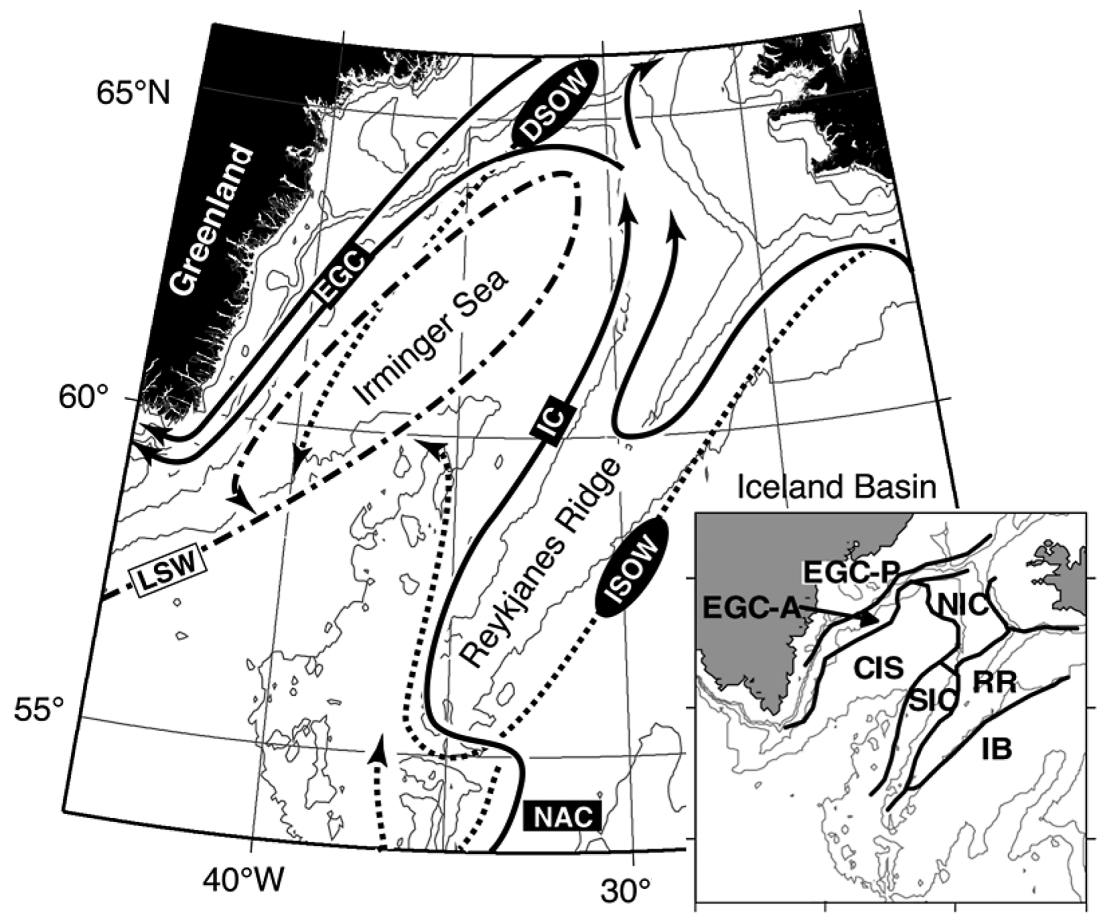

Fig. 1. Circulation in the Irminger Basin. Solid lines: surface circulation (NAC North Atlantic Current, IC - Irminger Current, EGC - East Greenland Current). Dot-dashed line: mid-depth circulation (LSW - Labrador Sea Water). Dotted lines: deep circulation (ISOW Iceland-Scotland Overflow Water, DSOW - Denmark Strait Overflow Water). Depth contours: 0, 500, 1000, 2000, 3000 , and $4000 \mathrm{~m}$. Inset: physical regions described in Table 1; IB: Iceland Basin. Reproduced from Holliday et al. (2006) and modified from Heath et al. (2008)

waters and serving as prey for mesozooplankton (see Irigoien et al. 2003). Here, we build on (1) our initial analysis of ciliate biomass and production in the Irminger Sea that recognised the localised importance of microzooplankton at frontal regions (Yebra et al. 2006) and (2) our study on the distribution and autecology of the functional autotrophic ciliate Myrionecta rubra that examined distributional patterns in the Irminger Sea (Montagnes et al. 2008).

The Irminger Sea is an oceanographically diverse region, influenced by waters of subtropical, subpolar, and polar origins in the upper $500 \mathrm{~m}$ of the water column. Within the Irminger Sea, distinct physical zones persist over the annual cycle, and unique hydrographic conditions (temperature, salinity, stratification, strength and depths of mixing, nutrient levels) have been identified. Details of the zones, their characteristics, biology and seasonal evolution are given in Read (2001) and Holliday et al. (2006). Seasonal, biological, and physical characteristics are summarised in Table 1.

The studies of Yebra et al. (2006) and Montagnes et al. (2008) were part of a concerted, UK-based effort to assess the
Table 1. Physical and biological characteristics of the zones for 3 seasonal cruises, based on the work by Holliday et al. (2006). Values: mean estimates over the upper mixed layer. Phytoplankton biomass was converted from chlorophyll (chl) a assuming a ratio of 1:50 (Waniek 2003). Chl a biomass was integrated over the top $100 \mathrm{~m}$ of the water column. Zones shown in Fig. 1, inset

\begin{tabular}{|c|c|c|c|c|c|}
\hline $\begin{array}{l}\text { Zone } \\
\text { (season) }\end{array}$ & $\begin{array}{l}\text { Mixed layer } \\
\text { depth (dbar) }\end{array}$ & Salinity & $\operatorname{SST}\left({ }^{\circ} \mathrm{C}\right)$ & $\begin{array}{c}\text { Phytoplankton } \\
\text { biomass }\left(\mathrm{ng} \mathrm{C} \mathrm{ml}^{-1}\right)\end{array}$ & $\begin{array}{c}\text { Nitrate } \\
(\mu M)\end{array}$ \\
\hline \multicolumn{6}{|c|}{ Central Irminger Sea (CIS) } \\
\hline Winter & 54 & 34.8 & 5.9 & $10-30$ & 11 \\
\hline Spring & $52-112$ & $34.9-35.0$ & $5.5-6.0$ & 30 & 13 \\
\hline Summer & $25-30$ & 34.9 & 9.6 & $25-45$ & $5-6$ \\
\hline \multicolumn{6}{|c|}{ Northern Irminger Current (NIC) } \\
\hline Winter & 150 & 35.0 & $7-8$ & $<5$ & 11 \\
\hline Spring & $27-90$ & 35.1 & $8.0-8.5$ & $30-100$ & $12-13$ \\
\hline Summer & $20-30$ & $35.0-35.1$ & $10-11$ & 45 & 5 \\
\hline \multicolumn{6}{|c|}{ Southern Irminger Current (SIC) } \\
\hline Winter & $50-150$ & $34.8-34.9$ & $6.8-7.5$ & $5-10$ & 9 \\
\hline Spring & $75-229$ & 35.1 & $6.7-7.5$ & $15-30$ & $12-12.5$ \\
\hline Summer & 25 & 35.1 & $10.0-10.5$ & $20-75$ & 6 \\
\hline \multicolumn{6}{|c|}{ East Greenland Current-Atlantic origin (EGC-A) } \\
\hline Winter & $280-300$ & 35.0 & 6.2 & $<10$ & $14.0-14.5$ \\
\hline Spring & 20 & 35.0 & 6.1 & 80 & $12-13$ \\
\hline Summer & 20 & $34.9-5.0$ & $8.8-10.3$ & $5-35$ & 4 \\
\hline \multicolumn{6}{|c|}{ East Greenland Current-polar origin (EGC-P) } \\
\hline Winter & - & $34.7-35.0$ & $3.0-5.5$ & $<5$ & 13 \\
\hline Spring & 12 & $34.1-34.4$ & $1.6-4.4$ & $105-150$ & $5.9-8.7$ \\
\hline Summer & surface & $33.9-34.0$ & $5.6-6.2$ & $35-55$ & 0.0 \\
\hline \multicolumn{6}{|c|}{ Reykjanes Ridge (RR) } \\
\hline Winter & 117 & 35.1 & 7.9 & 5 & $12.6-12.8$ \\
\hline Spring & 41 & 35.2 & 7.7 & $35-45$ & $11.2-12.3$ \\
\hline Summer & 14 & $35.1-35.2$ & $11.0-11.2$ & 35 & $4.1-4.7$ \\
\hline
\end{tabular}


annual plankton dynamics of the Irminger Sea through the NERC-themed Marine Productivity programme. From this intensive and extensive effort, papers have been published on:

(1) physical oceanography and its control on phytoplankton (Waniek et al. 2005, Henson et al. 2006b, Holliday et al. 2006, Waniek \& Holliday 2006, Ward \& Waniek 2007), which suggested that stratification, mixing, and meteorological conditions influence phytoplankton distribution and the timing and magnitude of the spring bloom in distinct hydrographic regions of the Sea, and in general that phytoplankton biomass is high in the Greenland Shelf and low in the centre of the Sea;

(2) phytoplankton production and nutrient structure, with an emphasis on new production (Sanders et al. 2005, Henson et al. 2006a), which indicated negligible new production before April and after August, and that new production is diatom dominated and hence silica limited;

(3) the spatial demography of Calanus finmarchicus (Fielding et al. 2004, Lindeque et al. 2006, Heath et al. 2008), indicating, among other factors, that most recruitment is on the margins of the Sea;

(4) the feeding and production of mesozooplankton nauplii and adults (Irigoien et al. 2003, Castellani et al. 2008, Mayor et al. 2006), which indicated the importance of phytoplankton blooms and possibly ciliates as food for metazooplankton;

(5) the distribution, population structure, and growth of euphausids (Saunders et al. 2007), which indicated some patterns in the distribution of euphausids, similar to the physical regions outlined above.

However, to date, there has been a dearth of data presented on the temporal or spatial size structure of the primary producers, and there has been no indication as to how the spatial distribution of abundance of small phytoplankton might influence the flow of materials through microzooplankton, which the above studies suggest are important.

Although microzooplankton may increase rapidly in abundance, associated with the spring phytoplankton bloom, potentially grazing diatoms and other primary producers (e.g. Lynn \& Montagnes 1991), it is during the remainder of the year, when pico- and nanoplankton are abundant, that microzooplankton are more likely to dominate as grazers. Our field study did not capture the spring bloom in the Irminger Sea (see 'Materials and Methods'), and therefore the focus of this paper is on the time when microzooplankton may be relatively important as primary consumers. Here, we provide detailed information on the abundance of the $<10 \mu \mathrm{m}$ phytoplankton and microzooplankton. Then, we speculate on the potential of microzooplankton to control primary production. Specifically, we first address these questions:
(1) To what extent do small $(<10 \mu \mathrm{m})$ phytoplankton dominate in the Irminger Sea and potentially contribute to energy flow within the microbial foodweb (outside the spring bloom)?

(2) Are ciliates and heterotrophic dinoflagellates abundant (in terms of numbers and biomass)?

(3) Are heterotrophic dinoflagellates as abundant as ciliates, as other studies suggest (e.g. Lessard \& Swift 1986, Burkill et al. 1993, Verity et al. 1993, Jeong 1999, Levinsen et al. 1999, Sherr \& Sherr 2007)?

Then, as ciliates are easily characterised by the methods we employed (Strueder-Kypke \& Montagnes 2002), and there are methods to predict ciliate growth rates (Müller \& Geller 1993, Montagnes 1996), we use ciliates as a proxy for all microzooplankton to address the questions:

(4) Are there seasonal patterns in occurrence of ciliates?

(5) Is there patchiness of ciliates at a basin scale related to hydrographic features (Table 1)?

Finally in the Discussion we provide 'back of the envelope' calculations to evaluate if ciliate production could be sufficient to account for the removal of primary production in the $<10 \mu \mathrm{m}$ size fraction.

Our goal in this work is not to fully integrate microzooplankton into a model of the Irminger Sea. Rather, we suggest that answers to the above questions, combined with the other studies of this region, will encourage researchers to place microzooplankton and their small prey within future trophodynamic assessments of the Irminger Sea (a direction that to date has been overlooked); to this end we provide a framework to place our temporal and spatial data into ecosystem models of the region.

\section{MATERIALS AND METHODS}

Hydrography and ecology of the Irminger Sea . The Irminger Sea, located in the North Atlantic subpolar gyre (Longhurst et al. 1995), is bounded by Greenland to the northwest and Iceland to the northeast. The Denmark Strait connects the Irminger Sea with the Arctic Ocean, while the Reykjanes Ridge (RR), $\sim 1200 \mathrm{~km}$ southwest of Iceland, marks the boundary with the Iceland Basin to the east. The Labrador Sea forms the southwestern boundary, between Cape Farewell and the tip of the Reykjanes Ridge. Circulation within the Irminger Sea is generally cyclonic (Lavender et al. 2000, Pollard et al. 2004). The northward branch of the Irminger Current (IC) heads along the west side of the Reykjanes Ridge before turning southwest, south of Iceland; here it merges with cold, dense northern overflows before heading southwestwards in the relatively fresh East Greenland Current 
(EGC) (Bacon 2002). Due to the general cyclonic circulation, Ekman pumping occurs across the base of the Ekman layer, preconditioning the water column to convective overturning. During periods of strong meteorological forcing, particularly by winds, deep convection occurs down to $2000 \mathrm{~m}$ (Pickart et al. 2002, Bacon et al. 2003, Moore 2003, Pickart et al. 2003). Convection to such depths occurs irregularly, but winter overturning within the region typically reaches down to $500 \mathrm{~m}$ (Pickart et al. 2003, Holliday et al. 2006). For further detailed studies on the oceanography of this region see Waniek et al. (2005), Holliday et al. (2006), Waniek \& Holliday (2006), and Ward \& Waniek (2007).

Cruises. Data were collected during 3 cruises: winter (November-December 2001), spring (April-May 2002), summer (July-August 2002). These cruises did not capture the spring bloom. Temperature, salinity, and nutrient data (see Table 1) were also collected; for details see Waniek et al. (2005), Sanders et al. (2005), Holliday et al. (2006), Ward \& Waniek, (2007), and Heath et al. (2008). Many of the data have been archived at the British Oceanographic Data Centre (BODC; Liverpool, UK).

Sample analysis. Surface $(\sim 5 \mathrm{~m})$ phytoplankton, heterotrophic dinoflagellate, and ciliate samples were collected during the cruises (see figures for horizontal sample distributions). In addition, to assess depth distribution of ciliates (phytoplankton and heterotrophic dinoflagellate data were not available), a single transect was analysed in detail $\left(\sim 61^{\circ} \mathrm{N}, 40^{\circ} \mathrm{W}\right.$ to $60^{\circ} \mathrm{N}$, $29^{\circ} \mathrm{W}$ ), with 5 to 6 samples analysed in the top 100 to $400 \mathrm{~m}$ at each station (see figures for depths).

For phytoplankton and heterotrophic dinoflagellate composition analysis, $100 \mathrm{ml}$ samples were fixed with acid-Lugol's iodine (final concentration $1 \%$ ) and examined by inverted microscopy following the Utermöl method (settling for $>48 \mathrm{~h}$ ); heterotrophic dinoflagellates were categorised based on species identification. Phytoplankton species-specific carbon estimates were derived from predetermined cell volumes and volume: carbon relationships (Eppley et al. 1970). Although some picoplankton $(<2 \mu \mathrm{m})$, which may not settle quickly or at all, will be missed by this method of observation, this size class was recognised in all samples (from the raw data, $<2 \mu \mathrm{m}$ particles numbered $\sim 10^{3}$ to $10^{4} \mathrm{ml}^{-1}$ ) and are included in the analysis; however, we add the caveat that biomass and abundance of the $<5 \mu \mathrm{m}$ fraction are likely to be underestimated. Furthermore, hetero-mixotrophic flagellates, which could not be distinguished from strict autotrophs in Lugol's samples, may represent a portion of the $<5 \mu \mathrm{m}$ autotrophic fraction; thus, our assumption that this fraction is 'strictly autotrophic' may be erroneous. To assess ciliates, samples $(100 \mathrm{ml})$ were fixed with acid-
Lugol's iodine (final concentration 10\%), bleached with sodium thiosulphate, and $50 \mathrm{ml}$ were observed by inverted microscopy, as described above. In each sample, all ciliates were enumerated and linear dimensions measured using an image analysis system. Ciliate volumes were calculated assuming appropriate geometric shapes and converted to biomass assuming $0.19 \mathrm{pg} \mathrm{C} \mu \mathrm{m}^{-3}$ (Putt \& Stoecker 1989), after correction for fixation with 10\% Lugol's (assuming 10\% Lugol'sfixed samples are $70 \%$ the volume of $2 \%$ Lugol's-fixed samples; Castellani et al. 2008). Tintinnid volume was assumed to be $21 \%$ of lorica volume (authors' unpubl. data) and biomass was calculated as above. As grazing is size dependent, both in terms of the predator and the prey (Hansen et al. 1994, 1997), both prey (phytoplankton) and predators (heterotrophic dinoflagellates and ciliates) were binned into size classes based on length (see 'Results').

Distributional patterns. Spatial distribution of plankton abundance, biomass, and production were assessed by geostatistical analysis (for an overview of this method see Bulit et al. 2003, 2004). The spatial structure of abundance was determined using the empirical variogram as the basic tool (Goovaerts 1997). The empirical variogram is a mathematical function that allows description of the spatial variability of abundance, biomass, and production in terms of variance between pairs of samples at increasing distance. Empirical variograms were modelled to predict values at non-visited locations using ordinary kriging techniques (see Bulit et al. 2003, 2004). Omnidirectional spherical and Gaussian models were fit to the empirical variograms, using the weighted least-squares method (Cressie 1993), and their parameters were used for kriging contour maps. Variographic analysis was conducted using Variowin (Pannatier 1996) and S-Plus (MathSoft). Kriging predictions were mapped using Surfer 7.0 (Golden Software).

To investigate the effects of season and biogeographical region (i.e. zones defined by Holliday et al. 2006; Table 1, Fig. 1), multi-dimensional scaling (MDS) was applied to the ciliate assemblage, based on the abundance of each species at each sampling station. MDS was conducted using PRIMER v5.1 software (Plymouth, UK), with 100 iterations to generate plots. The axes on the MSD plots are unitless: the closeness (clustering) of points indicates the relative similarity of the ciliate taxonomic grouping at each sample station. The stress factor was used to indicate the quality of the fit of the data (Kruskal 1964, Clarke 1993).

Ciliate production. Data were obtained for surface samples $(\sim 5 \mathrm{~m})$ from each season. Maximum ciliate production was determined as the product of biomass and growth rate, assuming ciliate specific growth rate to be a function of biovolume and ambient temperature, following the equation of Müller \& Geller (1993). 


\section{RESULTS}

\section{Microzooplankton composition}

Virtually all of the numerically dominant, heterotrophic dinoflagellates were small, unidentifiable gymnodinoid species; note though that many 'autotrophic' dinoflagellates are likely mixotrophic (e.g. Stoecker 1999), and this study was not capable of identifying these; thus, we may have underestimated heterotrophy. Equally, some of our identifications based on morphology of strict heterotrophs may be incorrect as chloroplasts cannot be seen in Lugol's samples. Thus, we may have overestimated the number of heterotrophic dinoflagellates. Consequently, our focus was on ciliate composition, which is more easily characterised.

Approximately 80 ciliate morphotypes were recognised, although this could be an underestimate of diversity as Lugol's does not reveal sufficient morphological detail to recognise all species. There were 26 strombidiids, 16 tintinnids, 7 strobilidiids, 7 gymnostomes, $5 \mathrm{scu}-$ ticociliates, and the remainder were a variety of rare taxa including urotrichids, hypotrichs, and haptorids. We have not placed these into strict taxonomic groups, preferring higher-level vernacular terms, given the flux of ciliate taxonomy and the limits of Lugol's iodine to reveal structures. In each season, several species dominated (Fig. 2, Table 2), typically with strombidiids and strobilidiids being most abundant.
Table 2 . The 5 most abundant ciliate species in the Irminger Sea in each season and overall in all seasons (mean abundance in the basin). Numbers after names refer to unique but unidentified taxa. See Fig. 2 for details on species characterisation. Raw data archived at British Oceanographic Data Centre

\begin{tabular}{|lcll}
\hline Season & Rank & Species & $\begin{array}{c}\text { Abundance } \\
\text { (ind. ml }{ }^{-1} \text { ) }\end{array}$ \\
\hline \multirow{6}{*}{ All } & 1 & Strombidium sp. 2 & 0.78 \\
& 2 & Pseudotontonia simplicidens & 0.56 \\
& 3 & Lohmaniella oviformis & 0.25 \\
& 4 & Strombidium conicum & 0.18 \\
& 5 & Strombidium sp. 1 & 0.14 \\
Winter & 1 & Lohmaniella oviformis & 0.06 \\
& 2 & Unidentified ciliate sp. 3 & 0.05 \\
& 3 & Strombidium sp. 3 & 0.04 \\
& 4 & Strombidium sp. 1 & 0.03 \\
& 5 & Strombidium sp. 2 & 0.03 \\
& 1 & Strombidium sp. 2 & 1.54 \\
& 2 & Lohmaniella oviformis & 0.42 \\
& 3 & Strombidium conicum & 0.36 \\
& 4 & Strombidium sp. 1 & 0.29 \\
& 5 & Strombidium coronatum & 0.20 \\
Summer & 1 & Pseudotontonia simplicidens & 1.90 \\
& 2 & Strombidium sp. 2 & 0.37 \\
& 3 & Lohmaniella oviformis & 0.19 \\
& 4 & Strombidium sp. 4 & 0.17 \\
& 5 & Leegaardiella sp. 2 & 0.15 \\
& & &
\end{tabular}

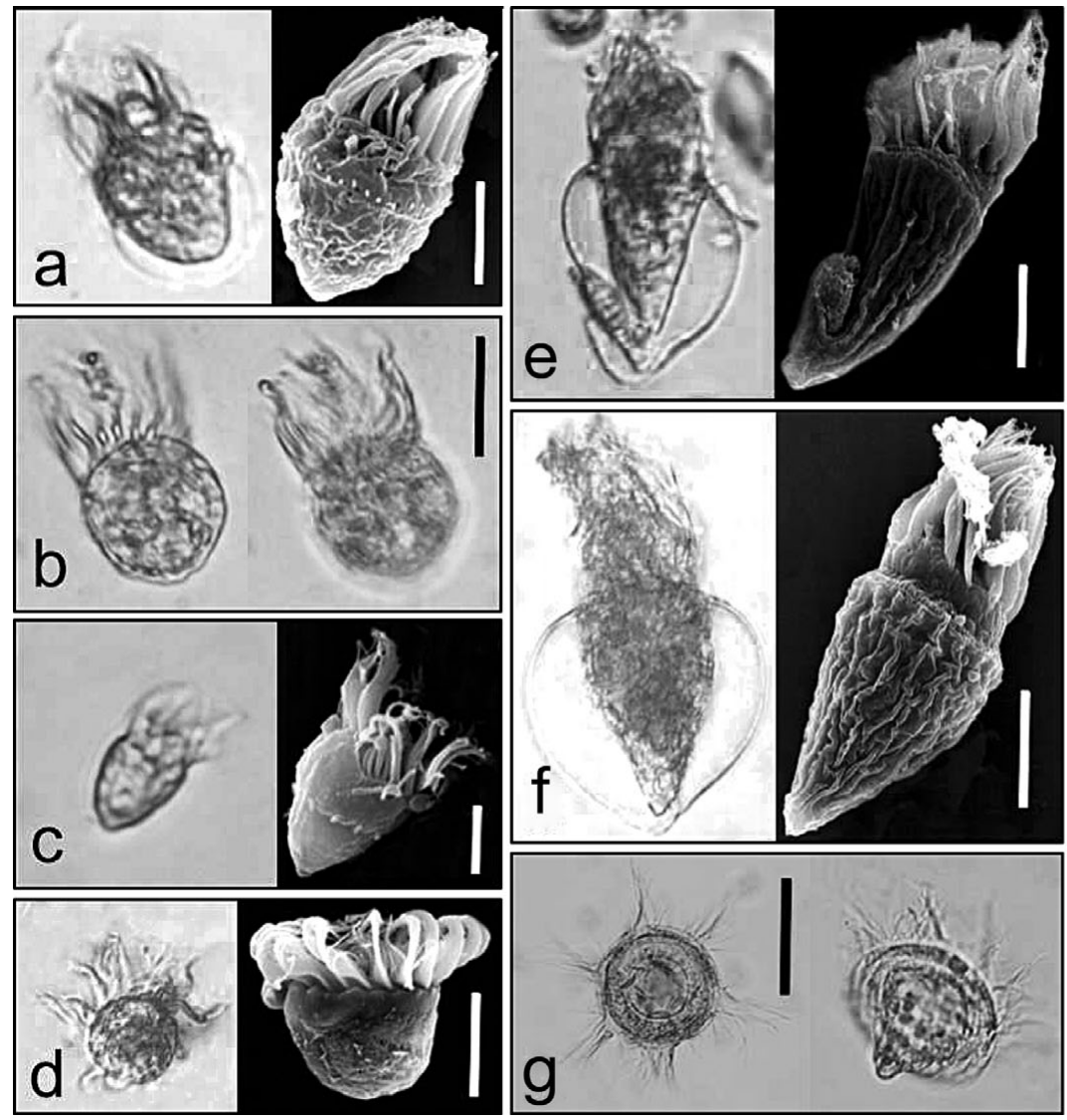

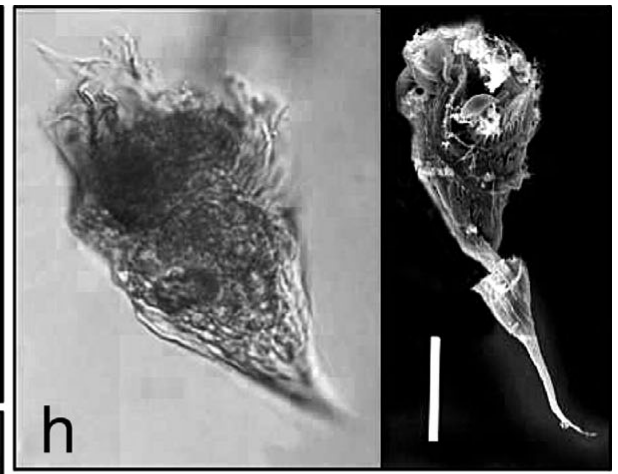

Fig. 2. Light and scanning electron micrographs of Lugol's fixed material from the Irminger Sea indicating all but 2 of the most abundant species observed (see Table 1 for details). (a) Strombidium sp. 2; (b) Lohmaniella oviformis, (c) Strombidium sp. 1; (d) Leegaardiella sp. 2; (e) Pseudotontonia simplicidens; (f) $S$. conicum; (g) unidentified ciliate sp. $3 ;$ (h) $S$. coronatum. No good preparations were available for Strombidium sp. 3 or 4 (see Table 2). Scale bars: $(\mathrm{a}, \mathrm{b}, \mathrm{d}, \mathrm{e}, \mathrm{f}, \mathrm{h})=10 \mu \mathrm{m} ;(\mathrm{c})=5 \mu \mathrm{m} ;(\mathrm{g})=20 \mu \mathrm{m}$ 


\section{Distribution of phytoplankton and ciliates}

Phytoplankton (Fig. 3)

Total winter phytoplankton biomass ranged from $\sim 2$ to $10 \mathrm{ng} \mathrm{C} \mathrm{ml} \mathrm{C}^{-1}$, with biomass increasing towards the southeast; the $<10 \mu \mathrm{m}$ fraction followed this pattern and represented most of the total phytoplankton biomass. Total spring phytoplankton biomass ranged from $\sim 50$ to $200 \mathrm{ng} \mathrm{C} \mathrm{ml}^{-1}$; the $<10 \mu \mathrm{m}$ fraction followed this pattern and represented 80 to $100 \%$ of the total phytoplankton biomass. Total summer phytoplankton biomass ranged from $\sim 10$ to $100 \mathrm{ng} \mathrm{C} \mathrm{ml}^{-1}$; the $<10 \mu \mathrm{m}$ fraction followed this pattern and represented 80 to $90 \%$ of the total phytoplankton biomass. Both spring and summer biomass increased towards the northwest off the Greenland coast.

\section{Ciliates (Figs. 4 to 6 )}

Winter abundance ranged from $\sim 0.2$ to 2 ind. $\mathrm{ml}^{-1}$ across the basin, with higher levels in the south
(Fig. 4a). Spring abundance ranged from $\sim 5$ to $10 \mathrm{ml}^{-1}$, with higher levels in the northwest (Fig. 4b). Summer abundance ranged from $\sim 2$ to 8 ind. $\mathrm{ml}^{-1}$, with higher levels in the north (Fig. 4c). Generally, cells occurred in the upper 50 to $100 \mathrm{~m}$ (Fig. 4a,b,c, lower panels).

Winter biomass ranged from $\sim 1$ to $8 \mathrm{ng} \mathrm{C} \mathrm{ml} \mathrm{Cl}^{-1}$ across the basin, with higher levels in the south (Fig. 5a). Spring biomass ranged from $\sim 4$ to $10 \mathrm{ng} \mathrm{C} \mathrm{ml}^{-1}$, with a uniform distribution (Fig. 5b). Summer biomass ranged from $\sim 8$ to $32 \mathrm{ng} \mathrm{C} \mathrm{ml}^{-1}$, with higher levels in the northeast (Fig. 5c). Generally, higher levels occurred in the upper 50 to $100 \mathrm{~m}$ (Fig. 5a,b,c, lower panels).

Estimates of winter maximum production ranged from $~ 0.6$ to $3 \mathrm{ng} \mathrm{C} \mathrm{ml} \mathrm{C}^{-1} \mathrm{~d}^{-1}$ across the basin, with higher levels in the south (Fig. 6a) and slightly higher levels in the upper $100 \mathrm{~m}$ (lower panel). Spring production ranged from $\sim 1$ to $3 \mathrm{ng} \mathrm{C} \mathrm{ml}^{-1} \mathrm{~d}^{-1}$, with higher levels to the east (Fig. 6b) and in the upper $100 \mathrm{~m}$, although data were limited for these estimates as temperature data were not available (lower panel). Summer production ranged from $\sim 2$ to $6 \mathrm{ng} \mathrm{C} \mathrm{ml}^{-1} \mathrm{~d}^{-1}$, generally with higher levels in the north-east (Fig. 6c) in the upper $50 \mathrm{~m}$ (lower panel).
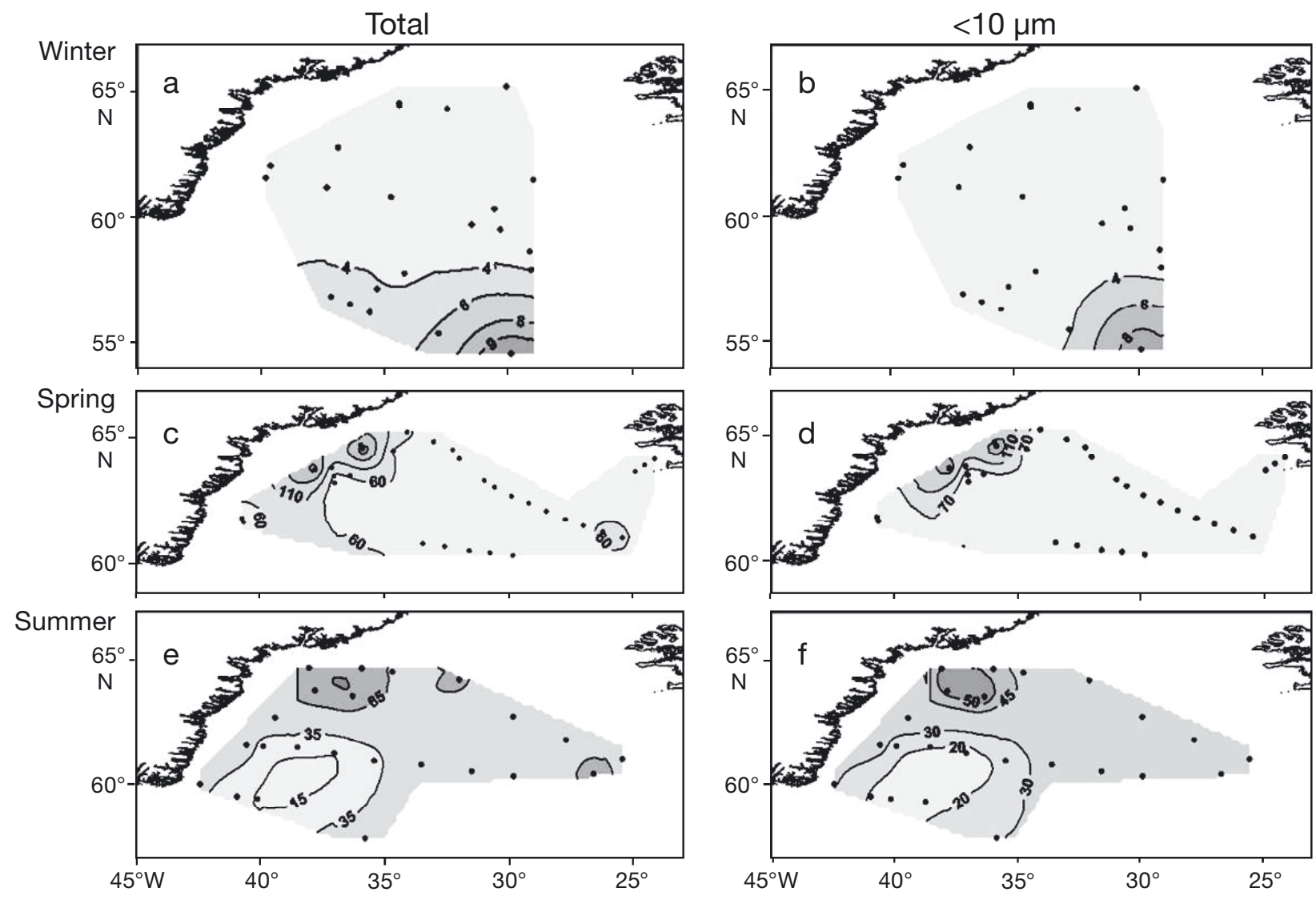

Fig. 3. Size fractionated phytoplankton biomass $\left(\mathrm{ng} \mathrm{C} \mathrm{ml}^{-1}\right)$ in surface $(\sim 5 \mathrm{~m})$ waters across the Irminger Sea. Shading: relative quantity of biomass (not consistent between panels). Dots: sampling sites 
a) Winter
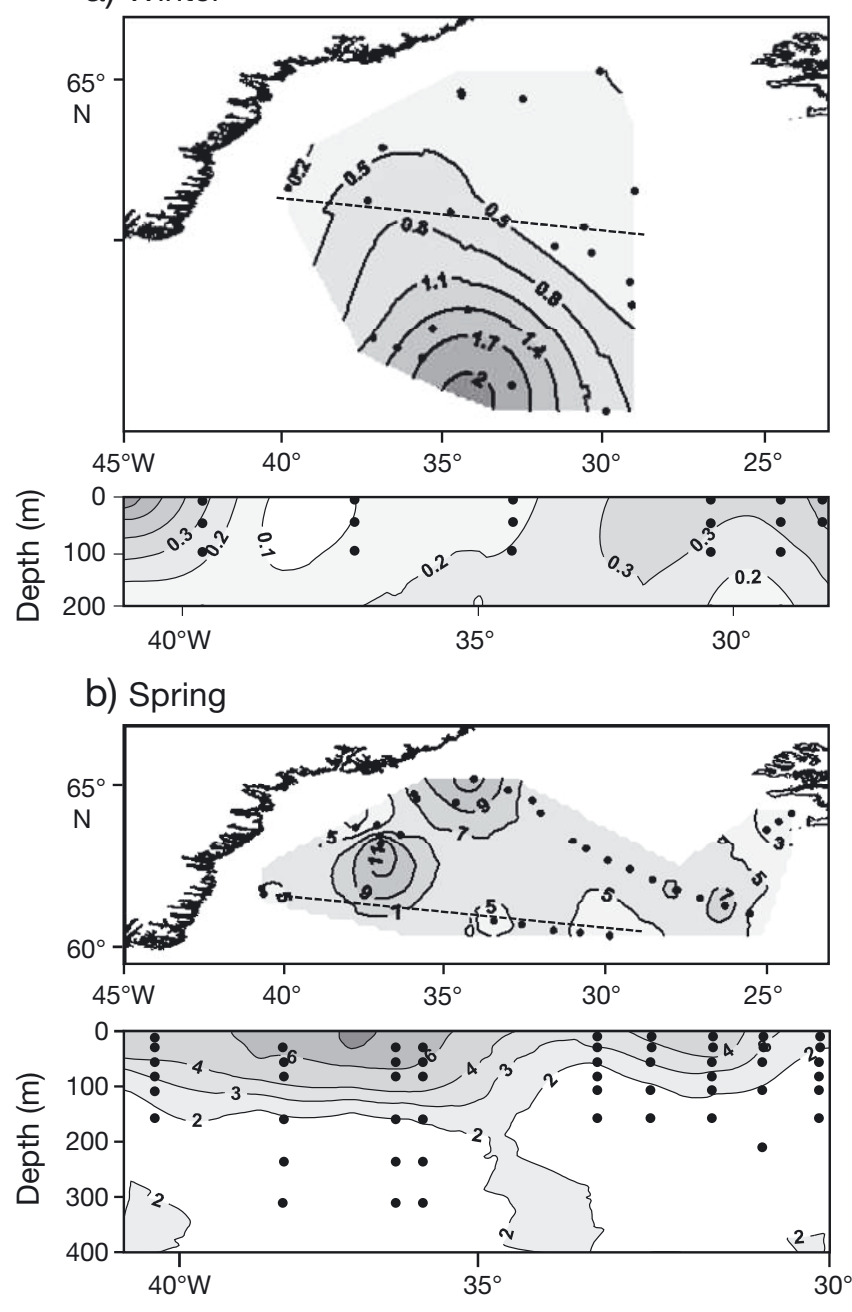

c) Summer

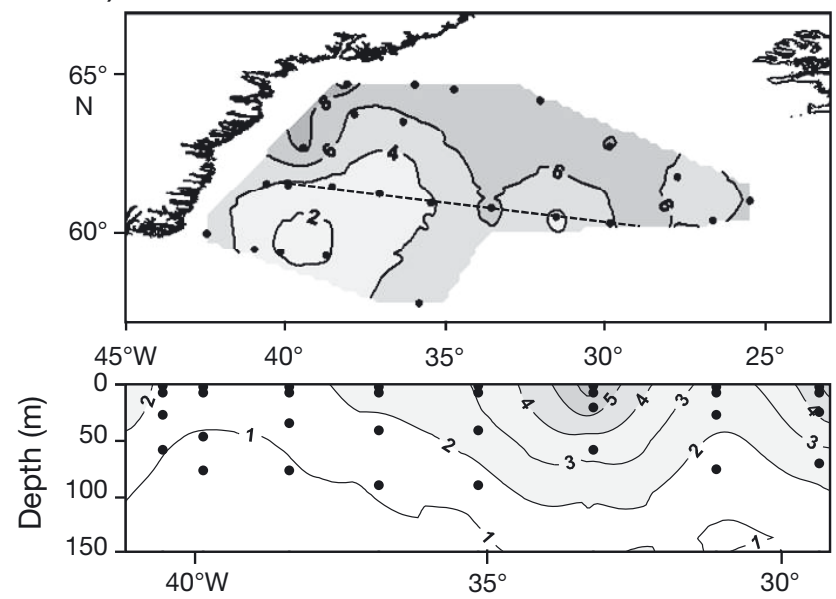

Fig. 4. Total ciliate abundance $\left(\mathrm{ml}^{-1}\right)$ in surface waters across the Irminger Sea and on a vertical transect across the middle of the basin. Abundances: (a) winter; (b) spring; (c) summer. Shading: relative quantity of abundance (not consistent between panels). Upper panels: sampling sites, surface distribution $(\sim 5 \mathrm{~m})$ and horizontal transect from $\sim 61^{\circ} \mathrm{N}, 40^{\circ} \mathrm{W}$ to $60^{\circ} \mathrm{N}$, $29^{\circ} \mathrm{W}$ (dotted line); lower panels: vertical (depth) profile a) Winter

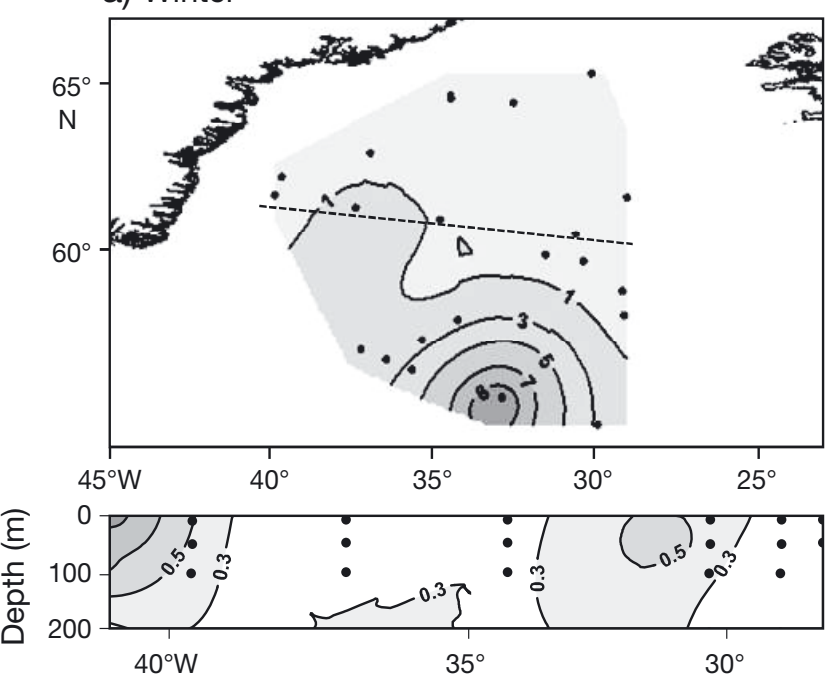

b) Spring
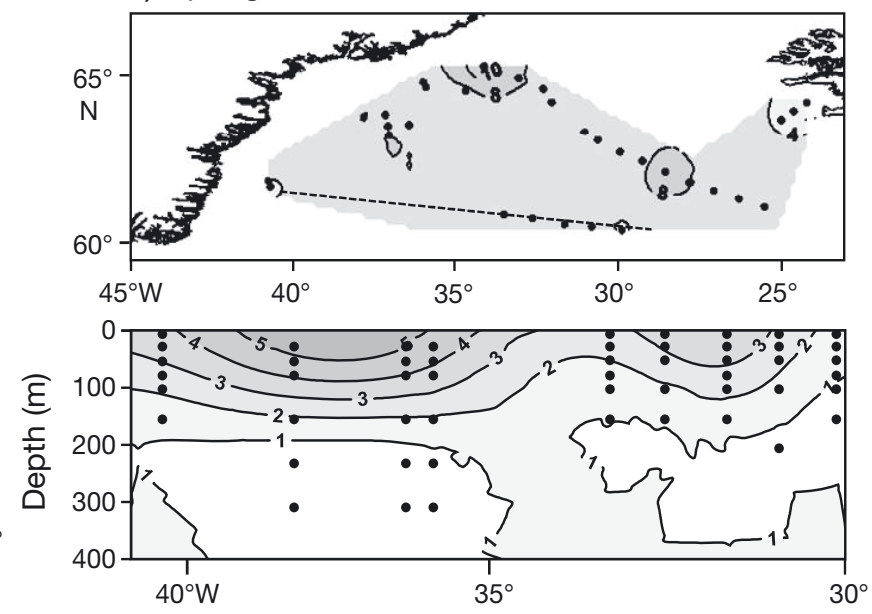

c) Summer

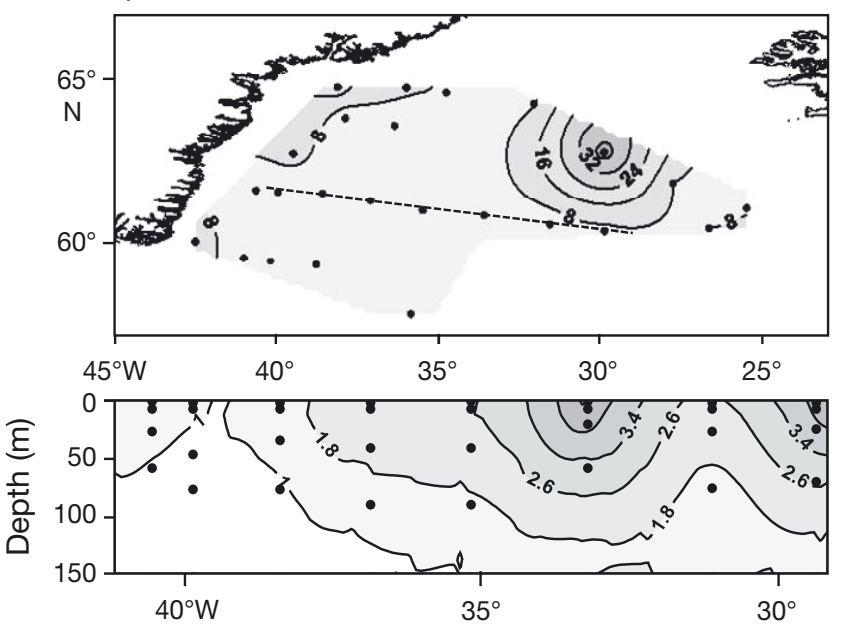

Fig. 5. Total ciliate biomass $\left(\mathrm{ng} \mathrm{C} \mathrm{ml}^{-1}\right.$ ) in surface waters across the Irminger Sea and on a vertical transect across the middle of the basin. See Fig. 4 for figure explanation 
a) Winter

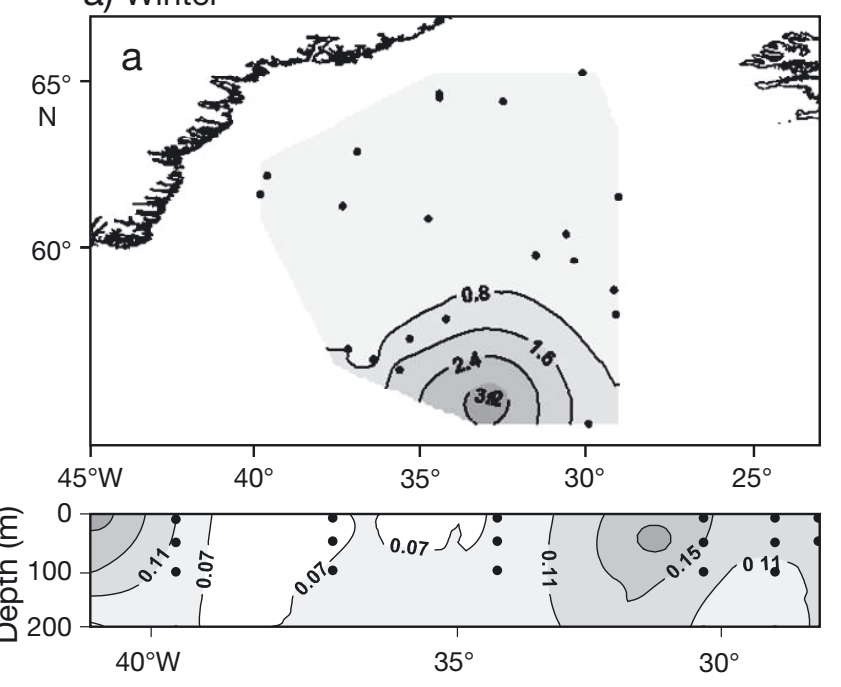

b) Spring

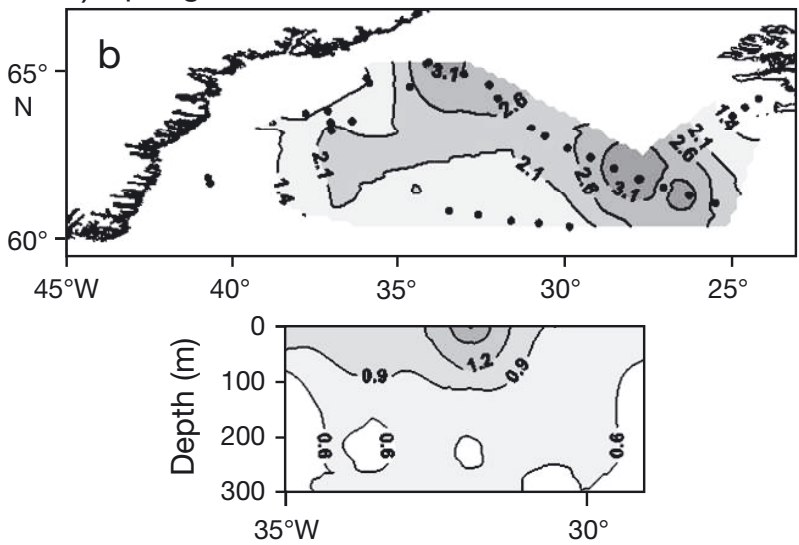

c) Summer

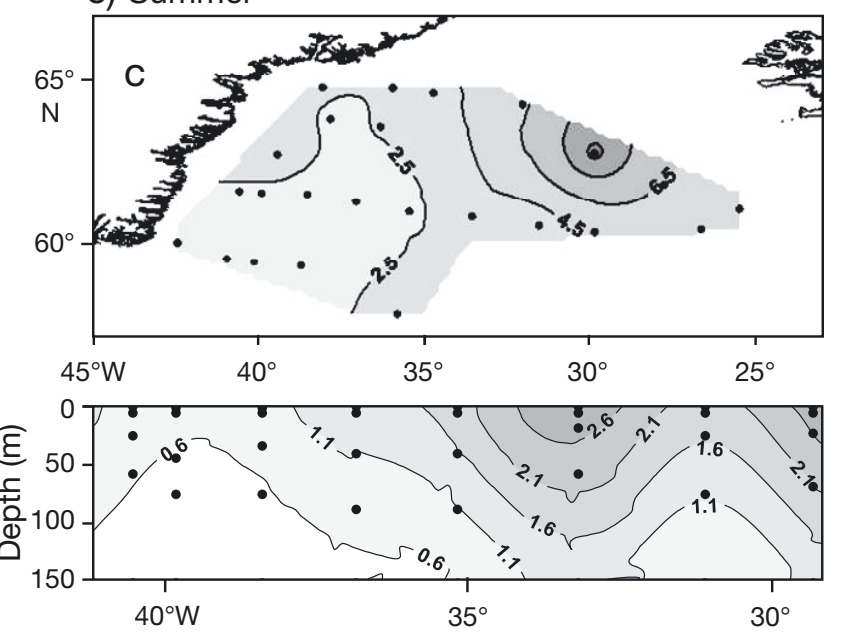

Fig. 6. Total ciliate production $\left(\mathrm{ng} \mathrm{C} \mathrm{ml} \mathrm{C}^{-1} \mathrm{~d}^{-1}\right)$ in surface waters across the Irminger Sea and on a vertical transect across the middle of the basin. See Fig. 4 for figure explanation

\section{Ciliate distribution patterns revealed by multidimensional scaling (Fig. 7)}

Multi-dimensional scaling indicated seasonal differences in the taxonomic-abundance composition of the ciliate assemblage. There was, however, no indication that the previously described zones in the Irminger Sea (Fig. 1, Table 1; see Holliday et al. 2006) contained distinct ciliate assemblages in any season. Consequently, we have omitted any detailed description of these potential patterns and the hydrographic zones. Our stress factors are relatively high $(>0.2)$ to the point where interpretation is questionable (Kruskal 1964, Clarke 1993) and our interpretation must be viewed with some caution.

\section{Size-fractionated phytoplankton, heterotrophic dinoflagellates, and ciliate abundance and biomass}

(Fig. 8)

Phytoplankton abundance was dominated by the $<5 \mu \mathrm{m}$ size class, and biomass was dominated by the $\leq 10 \mu \mathrm{m}$ fraction. Abundance increased from winter to summer, and biomass peaked in the spring. Heterotrophic dinoflagellates $<20 \mu \mathrm{m}$ dominated the microzooplankton numerically, but larger ciliates were generally more abundant than the dinoflagellates in the $>20 \mu \mathrm{m}$ size classes. Heterotrophic dinoflagellates increased in abundance from winter to summer, while ciliate abundance peaked in the spring. In contrast, ciliate biomass, in all size classes, was always greater than that of the heterotrophic dinoflagellates, and for both heterotrophic dinoflagellates and ciliates there was an overall increase in biomass from the winter to the summer.

\section{DISCUSSION}

\section{Importance of small phytoplankton}

One of the most notable results of this study is the first presentation of basin-wide distributions of sizefractionated phytoplankton for the Irminger Sea under non-spring bloom conditions; by doing so, we emphasise the need to collect and use microscope-based data on nano- and microplankton. From our work, it is evident that small $<10 \mu \mathrm{m}$ (and often $<5 \mu \mathrm{m}$ ) autotrophs dominate the primary producers in terms of numbers and biomass throughout the year in the Irminger Sea. Note that our estimates of total phytoplankton biomass based on cell counts are similar to biomass estimates made from chl a across the basin (Table 1), and that most of the biomass is in the smaller 

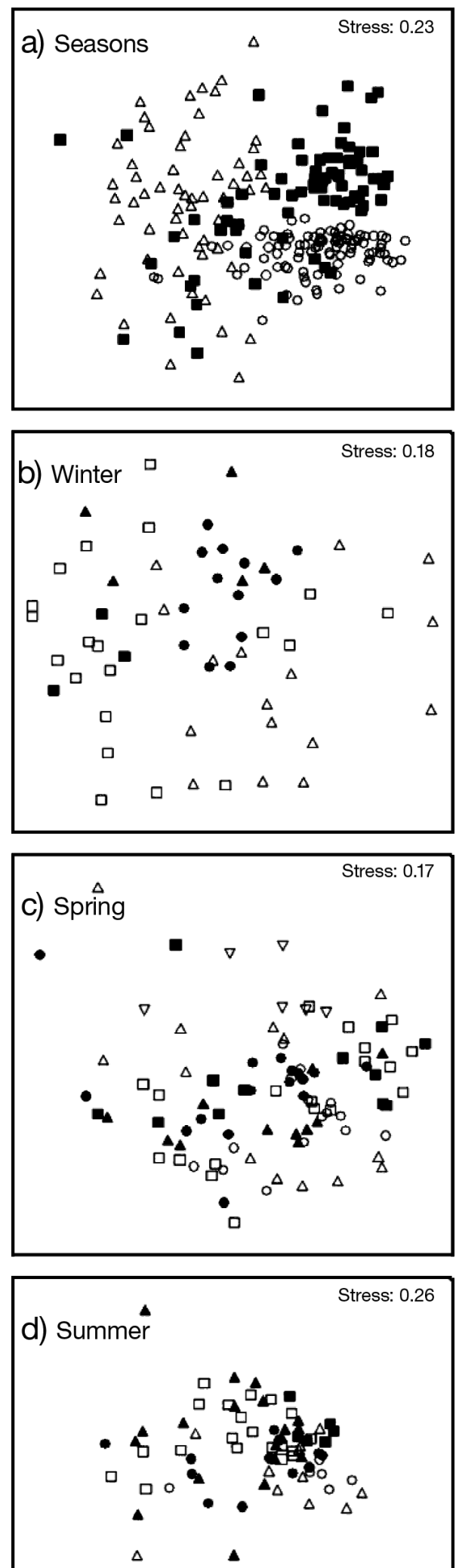

$\circ$ size fraction (Fig. 3). The dominance of small phytoplankton agrees with other Marine Productivity work in the Irminger Sea that determined size-fractionated chl a (Astoreca 2003). Furthermore, coastal studies of summer waters off Greenland indicate that $<11 \mu \mathrm{m}$ phytoplankton often dominate (Nielsen \& Hansen 1999), and other work in the Irminger Sea alludes to the dominance of small taxa (e.g. Irigoien et al. 2003, Mayor et al. 2006, Heath et al. 2008). Although these and other studies that focus specifically on phytoplankton production across the Irminger Sea (e.g. Sanders et al. 2005, Holliday et al. 2006) have documented the presence and role of small phytoplankton components (Waniek et al. 2005, Henson et al. 2006a), here we emphasise the importance of the spatial coincidence of patches of the autotrophic size-distribution and ciliate distribution as a predictor of predator-prey relationships (cf. Fig. 3d,f; Fig. 4b,c).

In non-spring bloom conditions, dominance by small phytoplankton is typical of many oceanic systems, especially where nutrients levels are low (e.g. Booth 1988, Boyd \& Harrison 1999), and this has long been recognised as critical in structuring food webs (e.g. Pomeroy 1974, Azam et al. 1983). Given that small phytoplankton are unavailable to, or are inefficiently captured by, most mesozooplankton and are the dominant prey for microzooplankton (Hansen et al. 1994, Hansen et al. 1997, Irigoien et al. 2003 and references therein), it is essential to focus on the microzooplankton when examining the foodweb dynamics of the Irminger Sea. By doing so, it will be possible to put in perspective the existing studies conducted in this region that focus on mesozooplankton and phytoplankton (see 'Introduction').

\section{Microzooplankton and their food}

As the Irminger Sea microzooplankton are poorly characterised, we first introduce the biota before assessing their roles and discussing their spatial distribution at basin scale. Although our best estimates of the heterotrophic dinoflagellates suggest that they dominate 'microzooplankton' abundance (as reported for

Fig. 7. Determination of temporal and spatial patterns of ciliate taxa by multidimensional scaling. (a) sample clustering of ciliate species diversity based on season: winter $(\Delta)$, spring $(\mathrm{O})$, summer ( $\mathbf{\square})$. Sample clustering of (b) winter, (c) spring, and (d) summer ciliate species diversity based on hydrographic zones (see Holliday et al. 2006, Fig. 1). Reykjanes Ridge $(\Delta)$; Iceland Shelf $(\nabla)$; Central Irminger Sea $(\boldsymbol{\Delta})$; South Irminger current $(\mathbf{O})$; North Irminger current $(\mathrm{O})$; East Greenland Current- Atlantic origin $(\square)$ and Polar origin ( $\square$ ). Stress: (a) 0.23 , (b) 0.18 , (c) 0.17 , (d) 0.26 


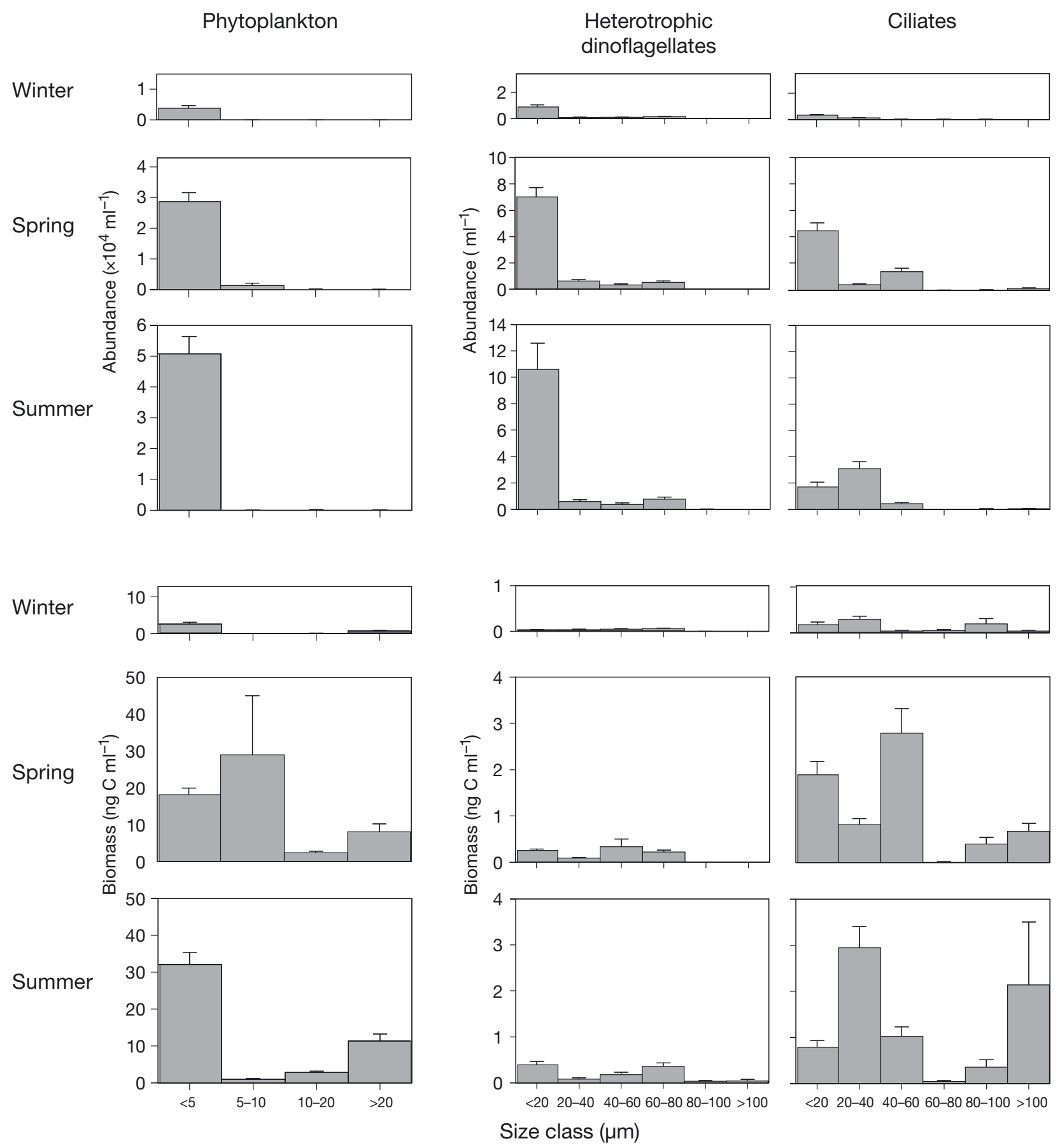

Fig. 8. Basinwide surface ( $5 \mathrm{~m})$ estimates of size-fractionated abundance and biomass of phytoplankton, heterotrophic dinoflagellates, and ciliates $($ mean $+\mathrm{SE})$; number of stations sampled: winter $=17$, spring $=32$, summer $=27$

adjacent waters; e.g. Burkill et al. 1993), the ciliates were dominant in terms of biomass. This differs from the findings of Burkill et al. (1993), which indicated that dinoflagellates (Gymnodiniidae and Peridiniidae) formed $\sim 40$ to $70 \%$ of the microzooplankton biomass in the northeastern Atlantic. We recognise that the dinoflagellates are an important heterotrophic component of the Irminger Sea food web, and the presence of heterotrophic species of Gymnodinium and Gyrodinium has also been reported by Waniek et al. (2005) and Ward \& Waniek (2007); we return to them in our analysis of average values across the basin (Fig. 8). However, as outlined above, in this study more and better data were collected on the ciliates; therefore, much of 
our analysis focuses on ciliates as a proxy for all microzooplankton, although this assumption may ignore the control that nano- and pico-sized protists can exert on small phytoplankton (Calbet 2008).

The Irminger Sea hosted a diverse assemblage of ciliates, at similar levels to those found in adjacent waters (e.g. Burkill et al. 1993, Gifford et al. 1995), but only a few were abundant (Fig. 2, Table 2). Furthermore, most of the dominant ciliates (and virtually all of the heterotrophic dinoflagellates) were $\leq 20 \mu \mathrm{m}$, indicating that it was nano- rather than microzooplankton (sensu Sieburth et al. 1978) that dominated the system. This abundance of extremely small heterotrophs undoubtedly reflects the size structure of their autotrophic prey, which tended to be $<5 \mu \mathrm{m}$, although there is the possibility that these small ciliates supplemented their diet with bacteria (Sherr et al. 1987), which were not examined in this study. It is also likely that the strombidiid ciliates, which were often most abundant, were mixotrophic (i.e. able to use prey chloroplasts to photosynthesise from hours to days; Stoecker 1998). Therefore, some of the proposed correlations between autotrophic prey and ciliates may not be appropriate.

\section{Distribution patterns, using ciliates as a proxy for microzooplankton}

Most of our sampling was conducted at a depth of $\sim 5 \mathrm{~m}$, so our observations reflect surface water patterns. Clearly though, the surface samples will overestimate entire water-column trends, as abundance tended to decrease with depth and there is mixing in the system (see 'Materials and methods, Hydrography and ecology of the Irminger Sea').

Although seasonal differences in the ciliate assemblage occurred, and ciliate abundance and biomass varied spatially, there was no indication (MDS) that their distributions reflected the proposed hydrographic zones associated with primary production (Fig. 1, Table 1; see Holliday et al. 2006, Waniek \& Holliday 2006). This lack of correlation is further supported by previous studies: Waniek \& Holliday (2006) recognised that little zonation in secondary production occurred, although it did exist for primary production and physical attributes; our previous work on mesozooplankton biomass distributions (Yebra et al. 2006) indicated that zooplankton did not follow the hydrographic regions; and our study of the phototrophic ciliate Myrionecta rubra indicated $\mathrm{km}$-scale patchiness across the Irminger Sea that was unrelated to the proposed hydrographic zones (Montagnes et al. 2008).

However, based on our analysis (Figs. 3 \& 4), there were similar horizontal distributional patterns of phytoplankton biomass and ciliate abundances within seasons, suggesting a positive predator-prey correlation, as might be expected (e.g. Lynn \& Montagnes 1991, Burkill et al. 1993, Calbet \& Saiz 2005). Maximal winter levels of ciliates abundance, biomass, and production tended to be in the southeast of the basin, possibly reflecting an influence of southern waters, driven by the Southern Irminger Current (Waniek et al. 2005). This current is associated with fronts between cool Sub-Arctic water to the west, and warm water from the North Atlantic Current (Holliday et al. 2006). Likewise, spring and summer ciliate abundance and spring biomass were highest near the east coast of Greenland, presumably because of the abundant autotrophic prey (e.g. Phaeocystis sp., <5 $\mu \mathrm{m}$ flagellates, picoplankton, some diatoms such as Chaetoceros sp., Nitzschia delicatissima, Thalassiosira gravida), due to the strong stratification promoted by meltwater runoff (Waniek et al. 2005, Holliday et al. 2006). However, summer ciliate biomass was highest towards the Reykjanes Ridge; where waters were warmer, a substantial increase of diatoms was observed (Waniek et al. 2005, Henson et al. 2006b), and primary production may be higher (Gudfinnson et al. 2008). Unlike the mesozooplankton, which grow in defined regions in the basin and are then dispersed elsewhere (Heath et al. 2008), it is more likely that patches of ciliates, and microzooplankton in general, in the Irminger Sea are localised, reflecting localised autotrophic production (e.g. Yebra et al. 2006).

Ciliate production indicated higher levels to the east of the basin. These were primarily temperature driven, as ciliate growth rate was temperature dependent (Müller \& Geller 1993), and temperatures in eastern waters were 2 to $5^{\circ} \mathrm{C}$ warmer than those influenced by the East Greenland Current (Holliday et al. 2006). Our maximum production estimates, however, may be biased, as ciliate taxa are likely temperature-adapted to local, colder regions (Levinsen et al. 1999), and thus growth rate may not be as temperature dependent as Müller \& Geller (1993) predict. Furthermore, the influence of food limitation in eastern waters may have been stronger than we recognised. Still, given the constraints of the study, we can provide an indication of potential variation and the upper limit of production.

In summary, although there may be basin-scale forcing, ciliate (and microzooplankton in general) patchiness across the Irminger Sea is due to localized regions of increased phytoplankton productivity: e.g. along the Greenland coast (e.g. Levinsen et al. 1999, Waniek et al. 2005, Holliday et al. 2006) or in localized upwelling events (see Yebra et al. 2006). Other studies in the Northeast Atlantic have also noted localised patchiness of microzooplankton (Quevedo et al. 2003) and short-term events for phytoplankton and microzooplankton dynamics (Gifford et al. 1995). As microzooplankton have growth rates that are similar to their 
prey and are able to exploit short-term blooms of phytoplankton (Banse 1982, 1992, Montagnes 1996), it would be expected that small-scale patches, on the order of $\mathrm{km}$ (or less), will occur, as in the Irish Sea (Montagnes et al. 1999) and in coastal lagoons (Bulit et al. 2003). This raises issues regarding our ability to assess or model microzooplankton dynamics from data that are typically collected at scales of 10 to $100 \mathrm{~km}$ (see Lynn \& Montagnes 1991, Montagnes 1996). With this caveat in mind, as most large scale surveys rarely examine small-scale patchiness, we next discuss the basin-wide role of ciliates, and microzooplankton in general, in the Irminger Sea.

\section{Production estimates and impact of ciliates}

In our work, a spring diatom bloom was not observed, as it occurred between the spring and summer cruises according to data from satellite chl and silicate drawdown (Henson et al. 2006b). Therefore, and in accord with others (e.g. Waniek et al. 2005), we indicate that outside the spring bloom, the autotrophs in the Irminger Sea are dominated by $<10 \mu \mathrm{m}$, and generally $<5 \mu \mathrm{m}$, cells: these are the typical prey for microand large nanozooplankton (e.g. ciliates) and are unavailable, or at the lower end of the size available, to mesozooplankton (Hansen et al. 1994, 1997, Irigoien et al. 2003 and references therein), suggesting that nanoand microzooplankton consume much of the primary production in this region.

To speculate on the potential for ciliates to graze these phytoplankton, average ciliate and phytoplankton production measurements and their standard errors were determined for each season. Maximum phytoplankton $(\leq 10 \mu \mathrm{m})$ and ciliate production were
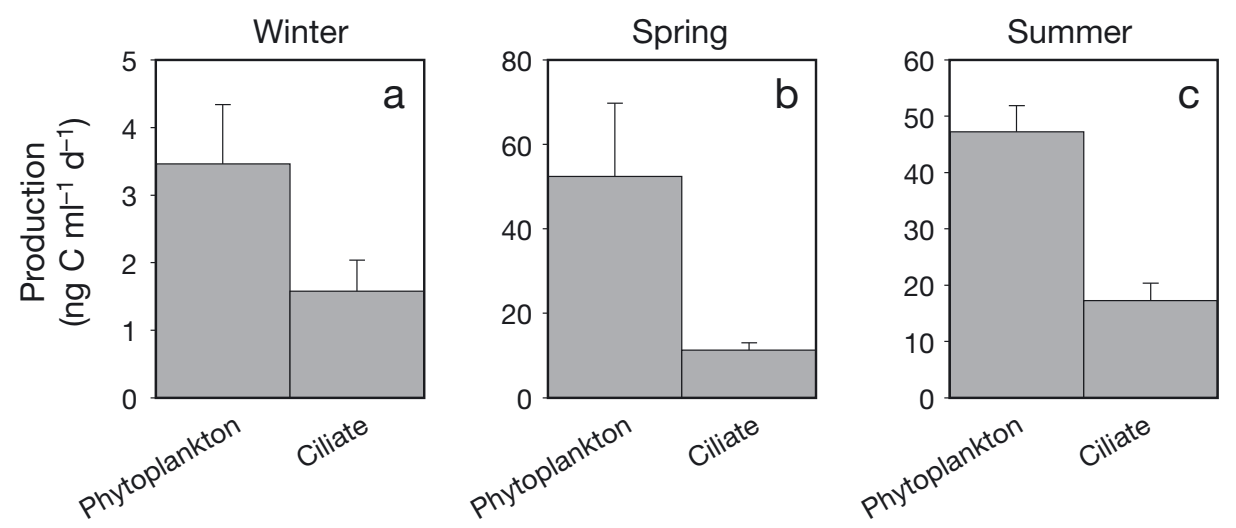

Fig. 9. (a-c) Primary production $(<10 \mu \mathrm{m}$ fraction) and ciliate production, and (d) \% primary production $(<10 \mu \mathrm{m}$ fraction) grazed by ciliates; data in (d) are mean and range, and not errors from statistical analysis, and should be used as a guide to the maximum and minimum predictions of mean values, rather than absolute values (see 'Discussion' for an explanation of their derivation) predicted following the temperature-dependent equation of Bissinger et al. (2008) and methods described above, respectively. Our predictions of 'maximum' primary production (Fig. 9), were, not surprisingly, higher than any estimates made in the region, as phytoplankton will often be nutrient or light-limited (e.g. Kirk 1994, Sanders et al. 2005). However, they were of the same order of magnitude as averages predicted over the year by the model of Waniek \& Holliday (2006); i.e. $\sim 8 \mathrm{ng} \mathrm{C} \mathrm{ml} \mathrm{C}^{-1} \mathrm{~d}^{-1}$ in the top $50 \mathrm{~m}$. Our predictions were also similar to those determined over the euphotic zone in mid-June 2003 to the west of the Reykjanes Ridge from ${ }^{14} \mathrm{C}$ incubations, i.e. $\sim 40 \mathrm{ng} \mathrm{C} \mathrm{ml}{ }^{-1} \mathrm{~d}^{-1}$ (Gudfinnson et al. 2008). More importantly, ${ }^{14} \mathrm{C}$-based estimates of primary production in the upper $10 \mathrm{~m}$ of the Irminger Sea, conducted during the UK Marine Productivity programme, were $\sim 25$ to $35 \mathrm{ng} \mathrm{C} \mathrm{ml}^{-1} \mathrm{~d}^{-1}$ in the summer cruise and 2 to $4 \mathrm{ng} \mathrm{C} \mathrm{ml}^{-1} \mathrm{~d}^{-1}$ in a second Marine Productivity winter cruise in 2002 (Astoreca 2003). Comparing our estimates with all those mentioned above, we suggest that surface primary production in the upper few meters of the Irminger Sea was on the order of $50 \%$ of that predicted by the relation of Bissinger et al. (2008).

Similar reduction of maximum ciliate production is also likely warranted. Laboratory studies on planktonic ciliates suggest that they have threshold levels (i.e. the prey concentration where growth rate is zero) at 10 to $50 \mathrm{ng} \mathrm{C} \mathrm{ml}^{-1}$; as prey levels increase, ciliates rapidly increase their growth to maximum rates at $\sim 100 \mathrm{ng} \mathrm{C}$ $\mathrm{ml}^{-1}$ (e.g. Montagnes 1996, Jeong 1999, Gismervik 2005). Thus, the potential prey levels in the upper waters of the Irminger (Fig. 3, Table 1) will rarely elicit maximum ciliate growth rates, but they may produce growth rates and hence production levels that are close to $50 \%$ of the maximum (see Montagnes 1996).

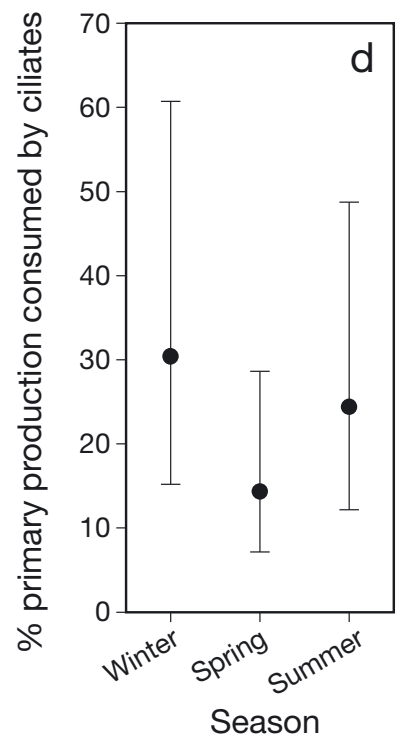


Based on the above arguments, ranges of ciliate grazing were predicted assuming in situ phytoplankton production (PP) and ciliate production (CP) might be reduced by at least $50 \%$ of their maximum, respectively, and ciliate gross growth efficiency (GGE) is $\sim 30 \%$ (Straile 1997). The percentage of the $\leq 10 \mu \mathrm{m}$ fraction of primary production possibly consumed by ciliates was then calculated as PP / CP × GGE, with estimates made where both productions were maximal and reduced by $50 \%$. These are 'back of the envelope calculations' to assess the potential impact of ciliates and must only be judged in this context.

Based on the above calculations, maximum ciliate and phytoplankton production followed a similar pattern, with low levels in the winter, an order of magnitude higher levels in the spring and summer, and maximum phytoplankton production always being $>2$ times that of ciliates (Fig. 9a-c). Estimates of the primary production consumed by ciliates were 15 to $30 \%$, but our bracketing suggests at least a range of 5 to $60 \%$ (Fig. 9d). These values agree with estimates of total microzooplankton grazing in the northeastern Atlantic that suggest that up to 40 and $100 \%$ of the $<20 \mu \mathrm{m}$ primary production in summer and spring, respectively, is grazed by microzooplankton (Gifford et al. 1995) and that 40 to $115 \%$ of the summer primary production is grazed by microzooplankton (Burkill et al. 1993). This is in accordance with the more general prediction that 60 to $75 \%$ of daily oceanic primary production is removed by microzooplankton grazing (Landry \& Calbet 2004).

However, we have only made average basinwide estimates, and as indicated above, the basin is not uniform. Site specific rate measurements should be a priority for future work in this region. Furthermore, our study was neither equipped to include the impact of small gymnodinoid dinoflagellates, the numerically dominant algivorous nanozooplankton (Verity et al. 1993), nor the impact of mixotrophic dinoflagellates. Given the abundance of these groups, it may be that the grazing of primary production by the nano- and microzooplankton as a group is double that of the estimates above. Thus, our work supports the arguments of others that nano- and microzooplankton are important grazers in open oceanic waters under non-spring bloom conditions (see Landry \& Calbet 2004), and they specifically provide evidence of the importance of this group in the Irminger Sea.

\section{Integrating nano- and microzooplankton into productivity of the Irminger Sea}

The Irminger Sea is a region of low primary production (Sanders et al. 2005), which is generally poor for copepod production (Heath et al. 2008). It is in these waters that ciliates and other microzooplankton contribute significantly (at times equal to phytoplankton) to the diet of copepods, and there may even be a preference by copepods for ciliates (Irigoien et al. 2003, Calbet \& Saiz 2005). Summer macronutrient levels in the basin are relatively high, leading to the suggestion that the autotrophs, which tend to be small flagellates, may be iron limited (Sanders et al. 2005). In other comparable open-ocean environments, nano- and microzooplankton play a large role in the grazing of autotrophic production and the rapid recycling of nutrients (Azam et al. 1983, Calbet 2008). In these cases, little of their production is transferred up the food web to zooplankton, and much of it will be respired as $\mathrm{CO}_{2}$. However, localised frontal blooms in the Irminger Sea may enhance mesozooplankton production directly via grazing on autotrophs (Calbet 2008, Heath et al. 2008) and by a grazing on microzooplankton that rapidly respond to the localised production (Yebra et al. 2006). It may also be that in the Irminger Sea copepod nauplii feed extensively on ciliates, but it is unlikely that they are sufficiently abundant to sustain metazooplankton (Irigoien et al. 2003). Finally, there are suggestions that microzooplankton are prey for fish larvae (reviewed by Montagnes et al. 2010) and may be an important supplement to their diet, providing nutritious prey when phytoplankton and mesozooplankton are scarce (Figueiredo et al. 2007). For all of these reasons, we contend that nano- and microzooplankton are major consumers of phytoplankton in the Irminger system and must be carefully parameterised in models of the North Atlantic.

Acknowledgements. We thank the crew of the RRS 'Discovery'. This study was conducted as part of the NERC-themed Marine Productivity programme, and was supported by NERC grants: NER/T/S/2001/00147, NER/T/S/2001/00694, and NE/C508334/1. We also thank J. Dower and Z. Yang for their constructive comments on a draft of the manuscript.

\section{LITERATURE CITED}

Astoreca R (2003) Phytoplankton production on the Irminger basin, NE Atlantic, in summer and winter 2002. MSc thesis. University of Southampton

Azam F, Fenchel T, Field JG, Gray JS, Meyer-Reil LA, Thingstad F (1983) The ecological role of water-column microbes in the sea. Mar Ecol Prog Ser 10:257-263

$>$ Bacon S (2002) A freshwater jet on the east Greenland shelf. J Geophys Res 107:3068

> Bacon S, Gould WJ, Jia Y (2003) Open-ocean convection in the Irminger Sea. Geophys Res Lett 30.

> Banse K (1982) Cell volume, maximal growth rates of unicellular algae and ciliates, and the role of ciliates in the marine pelagial. Limnol Oceanogr 27:1059-1071

Banse K (1992) Grazing, temporal changes of phytoplankton concentrations, and the microbial loop in the open sea. In: 
Falkowski PG, Woodhead AD (eds) Primary productivity and biogeochemical cycles in the sea. Plenum Press, New York, p 409-440

Bissinger JE, Montagnes DJS, Sharples J, Atkinson D (2008) Predicting marine phytoplankton maximum growth rates from temperature: improving on the Eppley curve using quantile regression. Limnol Oceanogr 53:487-493

Booth BC (1988) Size classes and major taxonomic groups of phytoplankton at 2 locations in the subarctic Pacific Ocean in May and August, 1984. Mar Biol 97:275-286

Boyd P, Harrison PJ (1999) Phytoplankton dynamics in the NE subarctic Pacific. Deep-Sea Res II 46:2405-2432

Bulit C, Díaz-Ávalos C, Signoret M, Montagnes DJS (2003) Spatial structure of planktonic ciliate patches in a tropical coastal lagoon: an application of geostatistical methods. Aquat Microb Ecol 30:185-196

Bulit C, Díaz-Ávalos C, Montagnes DJS (2004) Assessing spatial and temporal patchiness of the autotrophic ciliate Myrionecta rubra: a case study in a coastal lagoon. Mar Ecol Prog Ser 268:55-67

Burkill PH, Edwards ES, John AWG, Sleigh MA (1993) Microzooplankton and their herbivorous activity in the northeast Atlantic Ocean. Deep-Sea Res II 40:479-494

Calbet A (2008) The trophic roles of microzooplankton in marine systems. ICES J Mar Sci 65:325-331

Calbet A, Saiz E (2005) The ciliate-copepod link in marine ecosystems. Aquat Microb Ecol 38:157-167

Castellani C, Irigoien X, Mayor DJ, Harris RP, Wilson D (2008) Feeding of Calanus finmarchicus and Oithona similis on the microplankton assemblage in the Irminger Sea, North Atlantic. J Plankton Res 30:1095-1116

Clarke KR (1993) Non-parametric multivariate analyses of changes in community structure. J Ecol 18:117-143

Cressie N (1993) Statistics for spatial data. Wiley, New York

Eppley RW, Reid FMH, Strickland JDH (1970) Estimates of phytoplankton crop size, growth rate and primary production. Bull Scripps Inst Oceanogr 17:33-42

Fielding S, Mustard AT, Anderson CIH, Brierley AS, Heath MR (2004) Seasonal variation in the distribution of Calanus finmarchicus and its predators observed through multifrequency acoustics in the Irminger Sea. J Acoust Soc Am 115:2557

Figueiredo GM, Nash RDM, Montagnes DJS (2007) Do protozoa contribute significantly to the diet of larval fish in the Irish Sea? J Mar Biol Assoc UK 87:843-850

Gifford DJ, Fessenden LM, Garrahan PR, Martin E (1995) Grazing by microzooplankton and mesozooplankton in the high-latitude North Atlantic Ocean: spring versus summer dynamics. J Geophys Res 100:6665-6675

Gismervik I (2005) Numerical and functional responses of choreo- and oligotrich planktonic ciliates. Aquat Microb Ecol 40:163-173

Goovaerts P (1997) Geostatistics for natural resource evaluation. Oxford University Press, New York

Gudfinnson HG, Debes H, Falkenhaug T, Gaard E and others (2008) Abundance and productivity of the pelagic ecosystem along a transect across the northern Mid Atlantic Ridge in June 2003. ICES CM 2008/C12, available at: www.frs.fo/ew/media/Ritger\%C3\%B0ir/2008/ICES_CM0 8_C12.pdf

Hansen B, Bjoernsen PK, Hansen PJ (1994) The size ratio between planktonic predators and their prey. Limnol Oceanogr 39:395-403

Hansen PJ, Bjornsen PK, Hansen BW (1997) Zooplankton grazing and growth: scaling within the 2-2000 $\mu \mathrm{m}$ body size range. Limnol Oceanogr 42:687-704

Heath MR, Rasmussen J, Ahmed Y, Allen J and 29 others
(2008) Spatial demography of Calanus finmarchicus in the Irminger Sea. Prog Oceanogr 76:39-88

> Henson SA, Sanders R, Holeton C, Allen JT (2006a) Timing of nutrient depletion, diatom dominance and a lower-boundary estimate of export production for Irminger Basin, North Atlantic. Mar Ecol Prog Ser 313:73-84

> Henson SA, Robinson I, Allen JT, Waniek JJ (2006b) Effect of meteorological conditions on interannual variability in timing and magnitude of the spring bloom in the Irminger Basin, North Atlantic. Deep-Sea Res I 53:1601-1615

> Holliday NP, Waniek JJ, Davidson R, Wilson D and others (2006) Large-scale physical controls of phytoplankton growth in the Irminger Sea. Part 1: hydrographic zones, mixing and stratification. J Mar Syst 59:201-218

Irigoien X, Titelman J, Harris RP, Harbour D, Castellani C (2003) Feeding of Calanus finmarchicus nauplii in the Irminger Sea. Mar Ecol Prog Ser 262:193-200

Jeong HJ (1999) The ecological roles of heterotrophic dinoflagellates in marine planktonic community. J Eukaryot Microbiol 46:390-396

Kirk JTO (1994) Light and photosynthesis in aquatic ecosystems, 2nd edn. Cambridge Univ Press, Cambridge

- Kruskal JB (1964) Multidimensional scaling by optimizing goodness of fit to a nonmetric hypothesis. Psychometrika 29:1-27

Landry MR, Calbet A (2004) Microzooplankton production in the oceans. ICES J Mar Sci 61:501-507

Lavender KL, Davis RE, Owens WB (2000) Mid-depth recirculation observed in the interior Labrador and Irminger seas by direct velocity measurements. Nature 407:66-69

> Lessard EJ, Swift E (1986) Dinoflagellates from the Northern Atlantic classified as phototrophic or heterotrophic by epifluorescence microscopy. J Plankton Res 8:1209-1215

> Levinsen H, Nielsen TG, Hansen BW (1999) Plankton community structure and carbon cycling on the western coast of Greenland during the stratified summer situation. II. Heterotrophic dinoflagellates and ciliates. Aquat Microb Ecol $16: 217-232$

> Lindeque SH, Hay SJ, Heath MR, Ingvarsdottir A, Rasmussen J, Smerdon G, Waniek JJ (2006) Integrating conventional microscopy and molecular analysis to analyse the abundance and distribution of four Calanus congeners in the North Atlantic. J Plankton Res 28:221-238

Longhurst A, Sathyendranath S, Platt T, Caverhill C (1995) An estimate of global primary production in the ocean from satellite radiometer data. J Plankton Res 17:1245-1271

Lynn DH, Montagnes DJS (1991) Global production of heterotrophic marine planktonic ciliates. In: Reid PC, Turley CM, Burkill PH (eds) Protozoa and their role in marine processes. NATO ASI Series, Springer Verlag, New York, p 281-307

> Mayor DJ, Anderson TR, Irigoien X, Harris R (2006) Feeding and reproduction of Calanus finmarchicus during nonbloom conditions in the Irminger Sea. J Plankton Res 28: 1167-1179

Montagnes DJS (1996) Growth responses of planktonic ciliates in the genera Strobilidium and Strombidium. Mar Ecol Prog Ser 130:241-254

> Montagnes DJS, Poulton A, Shammon T (1999) Mesoscale, finescale, and microscale distribution of micro- and nanoplankton in the Irish Sea, with emphasis on ciliates and their prey. Mar Biol 134:167-179

- Montagnes DJS, Allen J, Brown L, Bulit C and others (2008) Factors controlling the abundance and size distribution of the phototrophic ciliate Myrionecta rubra in open waters of the North Atlantic. J Eukaryot Microbiol 55:457-465

Montagnes DJS, Dower JF, Figueiredo GM (2010) The proto- 
zooplankton-ichthyoplankton trophic link: an overlooked aspect of aquatic food webs. J Eukaryot Microbiol 57: $223-228$

Moore GWK (2003) Gale force winds over the Irminger Sea to the east of Cape Farewell, Greenland. Geophys Res Lett 30:1894

Müller H, Geller W (1993) Maximum growth rates of aquatic ciliated protozoa: the dependence on body size and temperature reconsidered. Arch Hydrobiol 126:315-327

Nielsen TG, Hansen BW (1999) Plankton community structure and carbon cycling on the western coast of Greenland during the stratified summer situation. I. Hydrography, phytoplankton and bacterioplankton. Aquat Microb Ecol 16:205-216

Pannatier Y (1996) Variowin: software for spatial data analysis in 2D. Springer-Verlag, New York

Pickart RS, Straneo F, Moore GWK (2002) Is Labrador Sea Water formed in the Irminger Basin? Deep-Sea Res I 50: 23-52

Pickart RS, Spall MA, Ribergaard MH, Moore GWK, Milliff RF (2003) Deep convection in the Irminger Sea forced by the Greenland tip jet. Nature 424:152-156

> Pollard RT, Read JF, Holliday NP, Leach H (2004) Water masses and circulation pathways through the Iceland Basin during Vivaldi 1996. J Geophys Res 109:C04004

Pomeroy LR (1974) The oceans food web, a changing paradigm. Bioscience 24:499-504

Putt M, Stoecker DK (1989) An experimentally determined carbon: volume ration for marine 'oligotrichous' ciliates from estuarine and coastal waters. Limnol Oceanogr 34: 1097-1103

Quevedo M, Viesca L, Anadon R, Fernandez E (2003) The protistan microzooplankton community in the oligotrophic north-eastern Atlantic: large- and mesoscale patterns. J Plankton Res 25:551-563

Read JF (2001) CONVEX-91: water masses and circulation of the Northeast Atlantic subpolar gyre. Prog Oceanogr 48: 461-510

Sanders R, Brown L, Henson S, Lucas M (2005) New production in the Irminger Basin during 2002. J Mar Syst 55: 291-310

Saunders RA, Ingvarsdóttir A, Rasmussen J, Hay SJ, Brierley AS (2007) Regional variation in distribution pattern, population structure and growth rates of Meganyctiphanes norvegica and Thysanoessa longicaudata in the Irminger

Editorial responsibility: Hans Heinrich Janssen, Oldendorf/Luhe, Germany
Sea, North Atlantic. Prog Oceanogr 72:313-342

Sherr EB, Sherr BF (2007) Heterotrophic dinoflagellates: a significant component of microzooplankton biomass and major grazers of diatoms in the sea. Mar Ecol Prog Ser 352: 187-197

- Sherr BF, Sherr EB, Fallon RD (1987) Use of monodispersed, fluorescently labelled bacteria to estimate in situ protozoan bacterivory. Appl Environ Microbiol 53:958-965

Sieburth JM, Smetacek V, Lenz J (1978) Pelagic ecosystem structure: heterotrophic compartments of the plankton and their relationship to plankton size fractions. Limnol Oceanogr 23:1256-1263

Stoecker DK (1998) Conceptual models of mixotrophy in planktonic protists and some ecological and evolutionary implications. Eur J Protistol 34:281-290

> Stoecker DK (1999) Mixotrophy among dinoflagellates. J Eukaryot Microbiol 46:397-401

Straile D (1997) Gross growth efficiencies of protozoan and metazoan zooplankton and their dependence on food concentration, predator-prey weight ratio, and taxonomic group. Limnol Oceanogr 42:1375-1385

> Strueder-Kypke M, Montagnes DJS (2002) Development of web-based guides to planktonic protists. Aquat Microb Ecol 27:203-207

> Verity PG, Stoecker DK, Sieracki ME, Burkill PH, Edwards ES, Tronzo CR (1993) Abundance, biomass and distribution of heterotrophic dinoflagellates during the North Atlantic spring bloom. Deep-Sea Res 40:227-244

> Waniek JJ (2003) The role of physical forcing in initiation of spring blooms in the Northeast Atlantic. J Mar Syst 39: $57-82$

> Waniek JJ, Holliday NP (2006) Large-scale physical controls on phytoplankton growth in the Irminger Sea, Part II: model study of the physical and meteorological preconditioning. J Mar Syst 59:219-237

> Waniek JJ, Holliday NP, Davidson R, Brown L, Henson SA (2005) Freshwater control of onset and species composition of Greenland shelf spring bloom. Mar Ecol Prog Ser 288:45-57

Ward BA, Waniek JJ (2007) Phytoplankton growth conditions during autumn and winter in the Irminger Sea, North Atlantic. Mar Ecol Prog Ser 334:47-61

> Yebra L, Harris RP, Wilson D, Davidson R, Montagnes DJS (2006) Epizooplankton summer production in the Irminger Sea. J Mar Syst 62:1-8

Submitted: April 29, 2009; Accepted: April 28, 2010 Proofs received from author(s): July 15, 2010 